\title{
Tidal, wave, current and sediment flow patterns in wet season in the estuary of Porong River Sidoarjo, Indonesia
}

\author{
Engki A. Kisnarti ${ }^{1, *}$, and Viv Dj. Prasita ${ }^{1}$ \\ ${ }^{1}$ Department of Oceanography, Hang Tuah University, J1. Arif Rahman Hakim 150, Surabaya- \\ Indonesia
}

\begin{abstract}
The objectives of this research are to analyze characteristics of physical oceanography, such as : tides, waves, currents, and discharges at Muara Kali Porong. This research also discuss sediment flow patterns and morphology in around the Estuary of Porong River. Tidal data were used as correction to the depth. The calculation to determine the tidal current velocity and wind data along with current data are used for simulation model. Sedimentation process with a simulation of 15 days in the West Season occured in the Northeast of Lusi Island with sediment thickness ranged from 1.6 to $2.6 \mathrm{~m}$.
\end{abstract}

\section{Introduction}

The bursts of mud and hot mudflow in Porong, Sidoarjo that have occurred since May 29, 2006 until today still continues, and there are no signs that this natural phenomenon will stop in the near future. The amount of mud volumes emerging from the center of the eruption is enormous, in 2006-2007 estimated at $100,000 \mathrm{~m}^{3} /$ day and even reaching $180,000 \mathrm{~m}^{3} /$ day in December 2006 , and tend to decrease to about $75,000 \mathrm{~m}^{3} /$ day in July 2009. The estimated volumes of bursts $50.000 \mathrm{~m}^{3} /$ day in September 2011. In 2006, the volumes of mud that went out continuously caused panic. With the rapid assessment of the government, it is determined that the mud should be discharged into the sea through the Porong River. This is in accordance with Presidential Regulation 14/2007 and its changes, the mud flow of Sidoarjo must be channeled into the sea through Porong River. [1].

The disposal of mud to Kali Porong has created disadvantages in various fields, both social, economic, and ecological. The mud flowing into Kali Porong adds to the adverse effects of human activities in the river catchment area on the ecology and biogeochemistry of the estuary and coastal waters of the Madura Strait [2]. The result of mud disposal into the estuary of Porong River are not only water quality changing. Remote sensing data is able to provide spatial and temporal information about other impacts of mud disposal to the Porong River. The results indicate that coastal mangrove areas have increased significantly due to Sidoarjo Mud (LUSI) - causing mudflow deposits near the mouth of the river [3].

" Corresponding author: engkiandri@hangtuah.ac.id 
Hydrodynamic model can also be used to know the sediment flow pattern in Muara Kali Porong [4], [5], [6]. The general distribution of sediment distribution in Porong waters shows mud sediments found on the banks of rivers and sand sediments found in the middle of the river. The basic sediments of the waters around the Porong estuary are sand, clay and silt lemps clay [7].

Research on the characteristics gradually has also been done, namely about the morphology in Estuary of Porong River which tends to be influenced by the accretion and abrasion process, as well as the tidal and currents relations around the Estuary of Porong River [8], [9]. To complement the research that has been done, it needs a more in-depth study with the purpose to analyze the physical characteristics (tides, waves, currents, discharges) flowing into Muara Kali Porong, sediment flow patterns to morphology, and coastline changes in around the Estuary of Porong River for 10-15 years with satellite imagery in the western season.

\section{Methodology}

\subsection{Study Area}

Porong river is a tributary of Brantas river which originated in the city of Mojokerto (Lengkong Baru Dam), flows eastward and empties into the Madura Strait. The name Porong is taken from the name of a sub-district located at the southern end of Sidoarjo regency. Porong River has two tributaries, Sadar River with $406.70 \mathrm{~km}^{2}$ of river flow that empties into Krembung Village and Kambing River with $196.60 \mathrm{~km}^{2}$ of river flow. Geographically, Porong river lies between $112.5^{\circ} \mathrm{BT}-112.9^{0} \mathrm{BT}$ and $7.3^{0} \mathrm{LS}-7.5^{0} \mathrm{LS}$ (Fig $1)$. This river is also the boundary of Sidoarjo and Pasuruan.

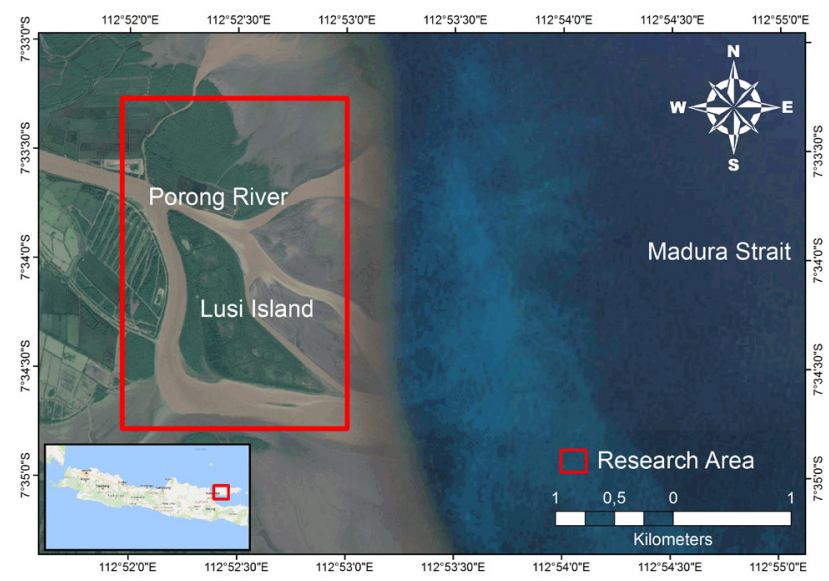

Fig. 1. Study area of Porong River

\subsection{Tidal data processing and bathymetri}

Tidal data is used as correction to the depth. The depth measurement data using echosounder is corrected by sea level position (MSL, $\mathrm{Z}_{0}$, and TWLt) at the time of measurement and correction of transducer distance to obtain the actual depth of the water [10].

Tidal has a function to correction of ocean depth data to obtain the true depth of the sea. Taking the data of ocean depth in Muara Porong is done using echosounder assisted by the 
motor boat with speed of boat speed 5 knot. The data obtained in the form of coordinates along with the depth captured by echosounder sensors. The depth measurement data using echosounder is then corrected to sea level position (MSL, Z0, and TWLt) at the time of measuement and correction of transducer distance to obtain the actual depth of the water. The reduction value (correction) measurement is obtained the following Equation (1) [10] :

$$
r t=T W L t-(M S L+Z 0)
$$

where

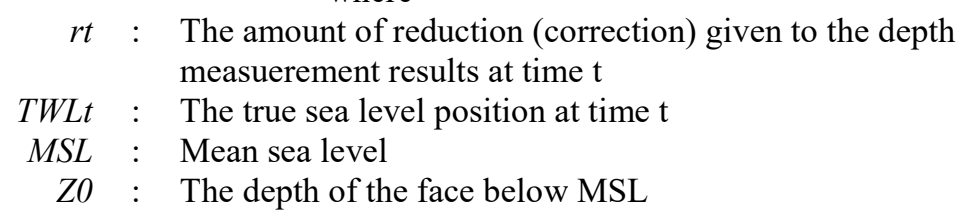

The result of Equation (4) is further used to obtain the actual depth by using the following Equation (2) [10] :

$$
\begin{aligned}
& D=d T-r t \\
& \\
D \quad: & \text { where } \\
d T: & \text { true depth } \\
r t & : \quad \text { Transparent depth of the transducer }
\end{aligned}
$$

Data of sea depth which have been calculated using Equation (1) and (2) got real depth data.

\subsection{Current data processing}

The calculation to determine the tidal current velocity is performed using the Equation (3) $[11]$.

$$
\text { Speed }=\sqrt{u^{2}+v^{2}}
$$

Likewise to determine the direction of the current, done with the calculation $\alpha$ first by Equation (4) [11].

$$
\alpha=\arctan \left(\frac{v}{u}\right) \text { atau } \alpha=\arctan \left(\frac{u}{v}\right)
$$
[11].

The calculation to determine the tidal current velocity is performed using Equation 5

$$
\text { Speed }=\sqrt{u^{2}+v^{2}}
$$

Likewise to determine the direction of the current, done with the calculation $\alpha$ first by Equation (6) [11]. 


$$
\alpha=\arctan \left(\frac{v}{u}\right) \text { atau } \alpha=\arctan \left(\frac{u}{v}\right)
$$

where

$u$ : Northern-Southern component of tidal current

$v$ : Eastern-Western component of tidal current

$u_{1}$ : Average Northern-Southern component

$v_{l}:$ Average Eastern -Western component

\subsection{River flow discharge}

River flow discharge $(Q)$, is the amount of water flowing through the cross section of the river per one unit of time, which is usually expressed in cubic meters per second [12]. River debit data is obtained from the Implementing Unit of Irrigation Area Technique, Porong.

\subsection{Wind}

Wind data obtained from the Meteorology, Climatology, and Geophysics Agency (BMKG) Surabaya. Wind data for 10 years is processed to obtain wind rose and used for wave forecasting.

Stages in wave forecasting:

$>$ Correction of location effects [13]:

The correction of the location effect is required because the wind data is derived from the ground station rather than measured directly above sea level or at the seashore. The relationship between sea breeze and terrestrial winds is shown by Equation 7 .

$$
R L=U_{W} / U_{L}
$$

where

$$
\begin{aligned}
U_{L}= & \text { wind speed on land } \\
U w= & \text { wind speed at sea } \\
R_{L}= & \text { relationship between the wind speed at sea and the wind on } \\
& \text { land }
\end{aligned}
$$

Conversion to wind voltage factor [13]

After the correction of the location effect then the next step is to convert the wind speed into a wind voltage factor as shown by Equation 8 .

$$
\begin{array}{cc}
\boldsymbol{U}_{\boldsymbol{A}}=0.71 \boldsymbol{U}^{1.23} & \text { where } \\
U_{A}= & \text { Wind stress factor }(\mathrm{m} / \mathrm{s}) \\
U= & \text { Wind speed }(\mathrm{m} / \mathrm{s})
\end{array}
$$

If the fetch length (F), wind stress factor (UA) and duration are known then high and significant wave periods can be calculated. To estimate the wave height to note the duration of kecepaan wind at sea, wind stress factors (UA) and the effective fetch. This estimation applies only to significant wave that is the average of $33 \%$ of the highest wave, of all waves that occur in waters that have been suspected wave height [12]. 
An effective fetch is a wave generating area with constant direction and wind. The effective fetch equation is denoted by Equation 9.

$$
F_{e f f}=\frac{\sum \mathrm{x}_{\mathrm{i}} \cos \alpha}{\sum \cos \alpha}
$$

Where $F_{\text {eff }}$ is Effective fecth average, $\mathrm{X}_{\mathrm{i}}$ is Length of the fetch segment measured from the wave observation point to the end of the fetch and $\alpha$ is deviations on both sides of the wind direction, using an increment of $6^{\circ}$ to an angle of $42^{\circ}$ on both sides of the wind direction

\subsection{Model of Simulation}

The simulation uses a 2-dimensional model that uses averaging to depth, and the parameters used are adjusted for application into the model.

\subsection{Hydrodynamic Model}

The purpose of simulating hydrodynamics is to obtain a current pattern that will affect the spread of the mud. The builder equation for hydrodynamics is:

The continuity equation

$$
\frac{\partial \zeta}{\partial t}+\frac{\partial u}{\partial x}+\frac{\partial v}{\partial y}=0
$$

The equation of momentum in the direction of $\mathrm{x}$ and $\mathrm{y}$

$$
\begin{aligned}
& \frac{\partial u}{\partial t}+u \frac{\partial u}{\partial x}+v \frac{\partial u}{\partial y}=-\frac{1}{\rho} \frac{\partial p}{\partial x}+2 \Omega v \operatorname{Sin} \varphi+F_{x} \\
& \frac{\partial v}{\partial t}+u \frac{\partial v}{\partial x}+v \frac{\partial v}{\partial y}=-\frac{1}{\rho} \frac{\partial p}{\partial y}-2 \Omega u \operatorname{Sin} \varphi+F_{y}
\end{aligned}
$$

where $\zeta$ is the water level elevation, $x$ and $y$ are Cartesian coordinates, $\mathrm{u}$ and $\mathrm{v}$ are velocities in the directions $-x$ and $-y, F_{x}$ and $F_{y}$ are forces in the $-x$ and $-y$ directions, $p$ is pressure, $\rho$ density, $g$ is acceleration of gravity, and $\varphi$ is the latitude of the Coriolis force.

\section{Result}

\subsection{Depth at Estuary of Porong River}

Bathymetry data was taken on March 6-9, 2017. The results of the depth data in estuary of Porong river can be seen in Figure 3. The research area in estuary of Porong river has a depth of 0.1-1.6 m. The average water depth along the river up to the estuary is $0.3-0.5 \mathrm{~m}$ indicated by light green color. In the estuary area there is a depth variation, although it is still dominated by green but has been mixed by the blue color indicating the addition of depth. The depth at the estuary ranges from 0.8 to $1.3 \mathrm{~m}$ indicated by the blue gradation. The depth of more than $1.4 \mathrm{~m}$ indicated by the purple color is on the east side of Lusi Island. 


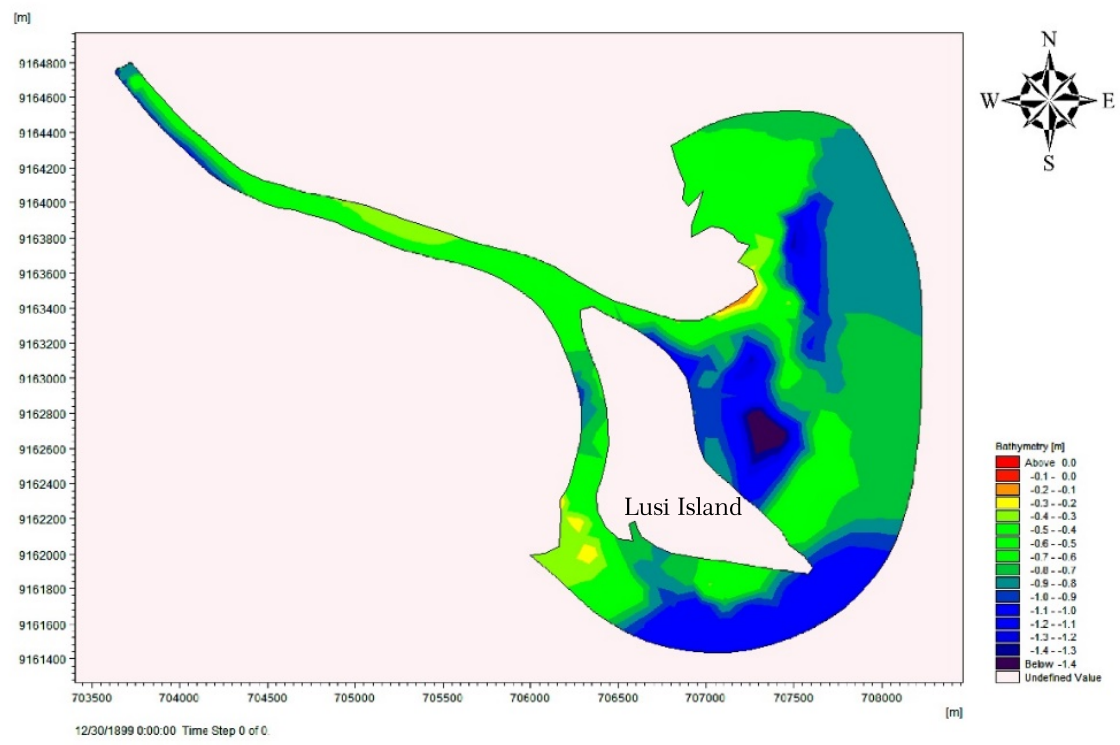

Fig. 2. Bathymetri in Estuary of Porong River, Sidoarjo.

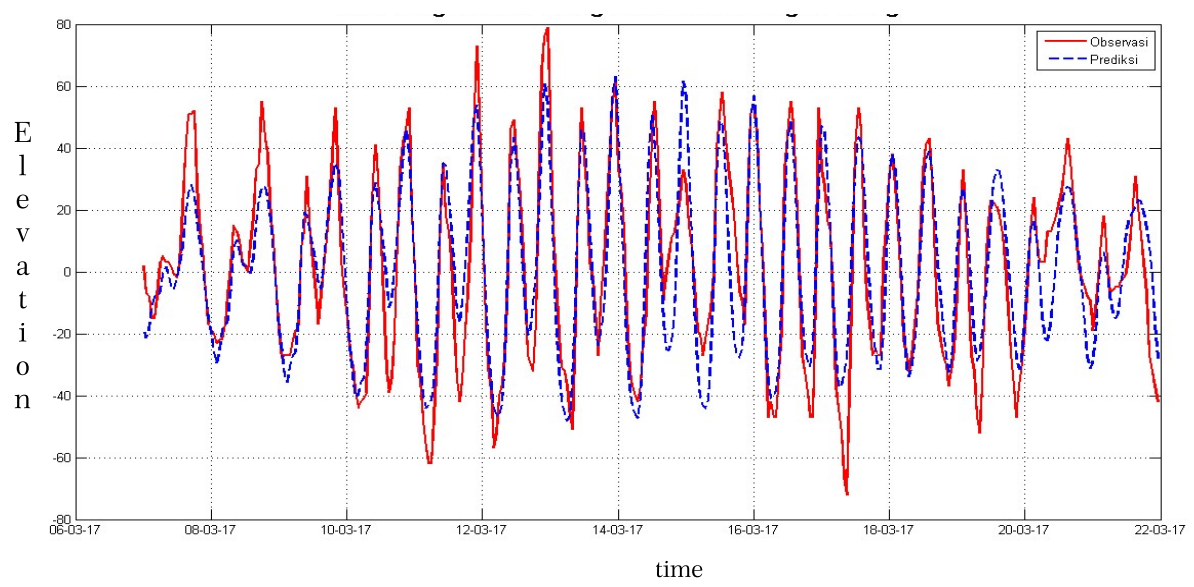

Fig. 3. Tidal charts in Estuary of Porong River.

\subsection{Tidal in the Estuary of Porong River}

Tidal observations in Porong River were conducted in March 2017 to represent the West season. Tidal types can be determined through tidal observation results from Figure 3 and Table 1. The result shows that the value of Formzahl is 0.62 . This figure indicates that the tidal type in Muara Kali Porong includes mixed type tends to double daily, ie within 24 hours of high water position and irregular low water inclined to double daily. This type of 
tidal is also similar to the results of research from Kisnarti and Prasita [8] and Kisnarti [9]. Mean Sea Level value in Muara Kali Porong is $117 \mathrm{~cm}$ from 0 palm.

Table 1. Amplitude and Phase Tidal in Estuary of Porong River

\begin{tabular}{|c|c|c|c|}
\hline Constants & Frequency & Amplitude & Phase \\
\hline$O_{1}$ & 0.0387307 & 11.0247 & 233.18 \\
\hline$K_{1}$ & 0.0417807 & 16.2428 & 329.58 \\
\hline$M_{2}$ & 0.0805114 & 26.7177 & 306.79 \\
\hline$S_{2}$ & 0.0833333 & 17.2121 & 0.15 \\
\hline$M_{3}$ & 0.1207671 & 5.0622 & 209.73 \\
\hline$S K_{3}$ & 0.1251141 & 2.4077 & 269.73 \\
\hline$M_{4}$ & 0.1610228 & 2.4213 & 233.69 \\
\hline$M S_{4}$ & 0.1638447 & 4.2672 & 290.61 \\
\hline$S_{4}$ & 0.1666667 & 1.6330 & 313.85 \\
\hline $2 M K_{5}$ & 0.2028035 & 1.1038 & 186.94 \\
\hline $2 S K_{5}$ & 0.2084474 & 0.7351 & 353.03 \\
\hline$M_{6}$ & 0.2415342 & 0.2516 & 300.10 \\
\hline $2 M S_{6}$ & 0.2443561 & 1.0064 & 194.35 \\
\hline $2 S M_{6}$ & 0.2471781 & 1.6031 & 180.84 \\
\hline $3 M_{7}$ & 0.2833149 & 0.6011 & 130.45 \\
\hline$M_{8}$ & 0.3220456 & 0.2804 & 178.31 \\
\hline
\end{tabular}

\subsection{Tidal in the Estuary of Porong River}

The observation of tidal current is done simultaneously with tidal observation in March 2017. The result of tidal current observation can be seen in Figure 4 and Figure 5. The current flow along the river before reaching the estuary is faster than the current in the estuary taht is $1-1.3 \mathrm{~m} / \mathrm{s}$ markedby gradations of green, yellow, and orange. The current velocity going to the eatuary is at the turn of Lusi Island on the East side hand had increased the current velocity up to $1.6 \mathrm{~m} / \mathrm{s}$ indicated by the red color, then the current flows towards the estuary towards the East and North waters.

On the west side of Lusi Island from the river to the estuary also experienced an increse in current velocity shown by the red color reaches $1.5 \mathrm{~m} / \mathrm{s}$. The curret that passes though the west side of Lusi Island out towards the estuary to the south of the waters. The occurrence of increased speed on the East and West side of Lusi Island when going out the estuary can be caused by physical condition or topography of the waters. Since water flows through the two branches of the creek it causes the current flow to turn and its speed increases. In addition, it can also be caused by the condition of the witdh of the river that originally narrowed then widened when going out towards the estuary. 

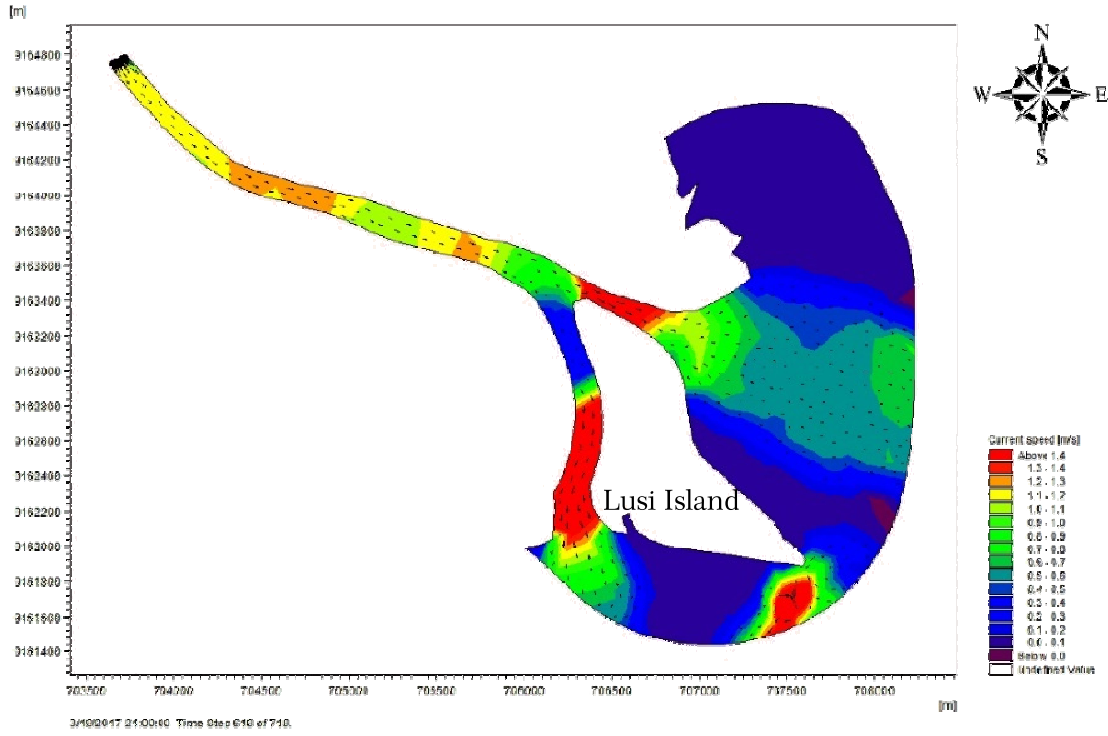

Fig. 4. Current during tide in Estuary of Porong River, Sidoarjo.

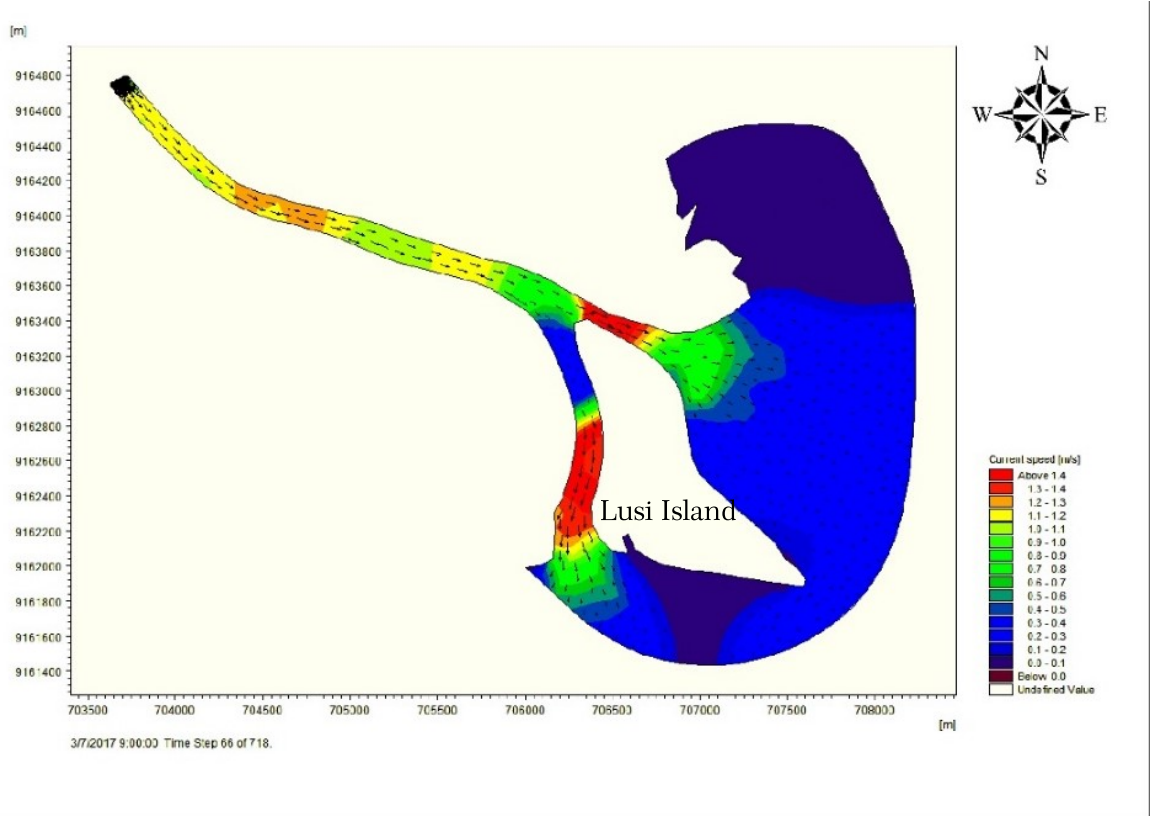

Fig. 5. The current at low tide in Estuary of Porong River, Sidoarjo.

\subsection{Discharge in the Estuary of Porong River}

Based on the results of river flow data processing in estuary of Porong River during the observation of $462,9 \mathrm{~m}^{3} / \mathrm{s}$, and river flow in March was equal to $569 \mathrm{~m}^{3} / \mathrm{s}$. The value of discharge during the rainy season was not must different from the discharge value during 
March 2017 which amounted to $578.9 \mathrm{~m}^{3} / \mathrm{s}$. Therefore, the speed of the Porong river flow in March 2017 is more dominated by river flow.

\subsection{Wind in the Estuary of Porong River}

The main wind in the West season tends to blow from the southwest and the second is from the west (Figure 6a). Speed 1-2 m/s has the highest frequency distribution percentage that is $42.34 \%$ with highest percentage from Southwest direction $10.91 \%$ and seconly from west direction $8.91 \%$. Speed $0-1 \mathrm{~m} / \mathrm{s}$ has the second highest frequency distribution percentage that is $40.35 \%$ with highest percentage of southwest direction $6.92 \%$ and second from south direction $5.61 \%$. The total data has an average speed of $1.26 \mathrm{~m} / \mathrm{s}$ and a significant wind speed of $2.29 \mathrm{~m} / \mathrm{s}$.
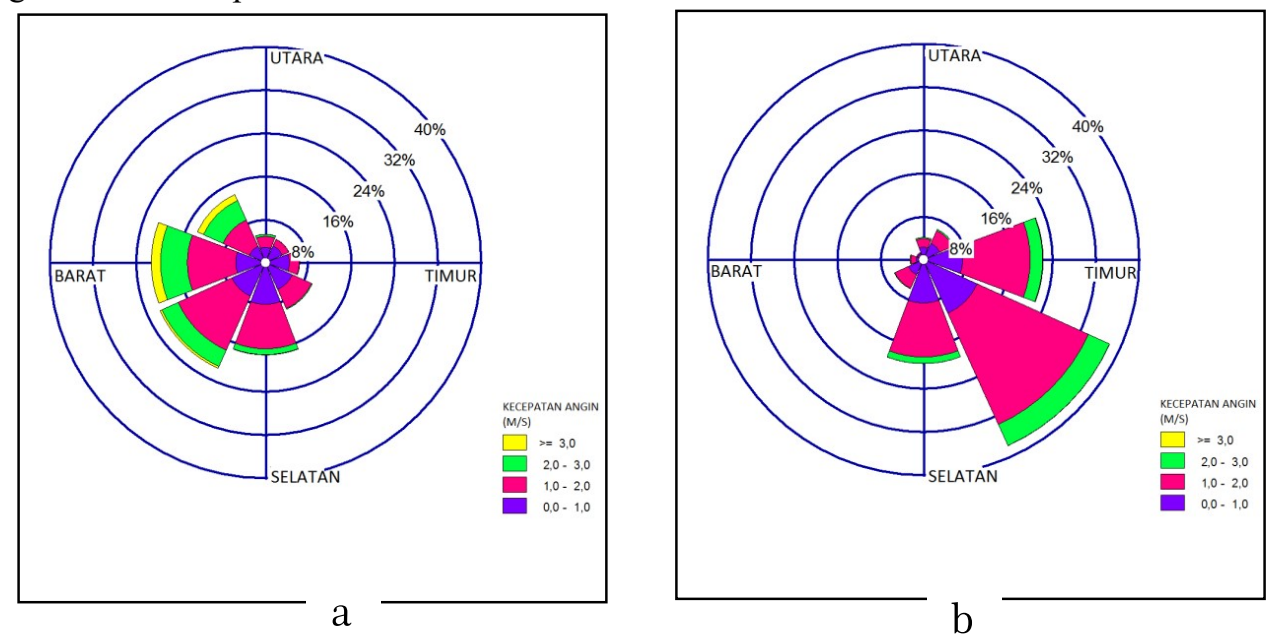

Fig. 6. Wind rose distribution in 2006-2015: (a) western session (b) transition session

The result of the wind data analysis during the transition season I shows that the main winds tend to be from the Southeast and the second direction from the East. (Figure 6b.) The main winds tend to be from the Southeast and the second is from the East. The speed of 1-2 $\mathrm{m} / \mathrm{s}$ has the highest frequency distribution with the overall total of $53 \%$ with the highest percentage of the Southeast $22.52 \%$ and the second of the East $12.44 \%$. The speed of $0-1 \mathrm{~m} / \mathrm{s}$ has the second highest frequency distribution with the overall total of $38.35 \%$ with the highest percentage of the Southeast direction of $11.00 \%$ and the second is from the East $7.35 \%$.

The average wind speed at Western and first transition session are 1.26 and $1.15 \mathrm{~m} / \mathrm{s}$ and a significant wind speed of 2.29 and $1.78 \mathrm{~m} / \mathrm{s}$ hence the average wind speed or significant less generating a minimum $U_{A}$ so that the wind is said to be weak and can not be used to predict the height and significant wave period.

\subsection{Suspension Sediment Analysis}

Using hydrodynamic model, simulation has been done based on tidal data input, current discharge and wave. The average different drift in the research area in estuary of Porong river for 15 days way $0.2-0.8 \mathrm{~kg} / \mathrm{m}^{3}$ as shown in Figure 8 through the dominant blue color 
gradation. In areas with high current velocities, the suspended sediment is higher at $3 \mathrm{~kg} /$ $\mathrm{m}^{3}$, indicated by red. Sediment suspension increasingly heading towards the estuary until the estuary is not too big about $0.2-0.8 \mathrm{~kg} / \mathrm{m}^{3}$. In the area leading to the sea the suspension becomes $1.4-2 \mathrm{~kg} / \mathrm{m}^{3}$, this may occur due to the confluence of river and sea water so that the turbulence is greater and causes the sediment to rise (Figure 7).

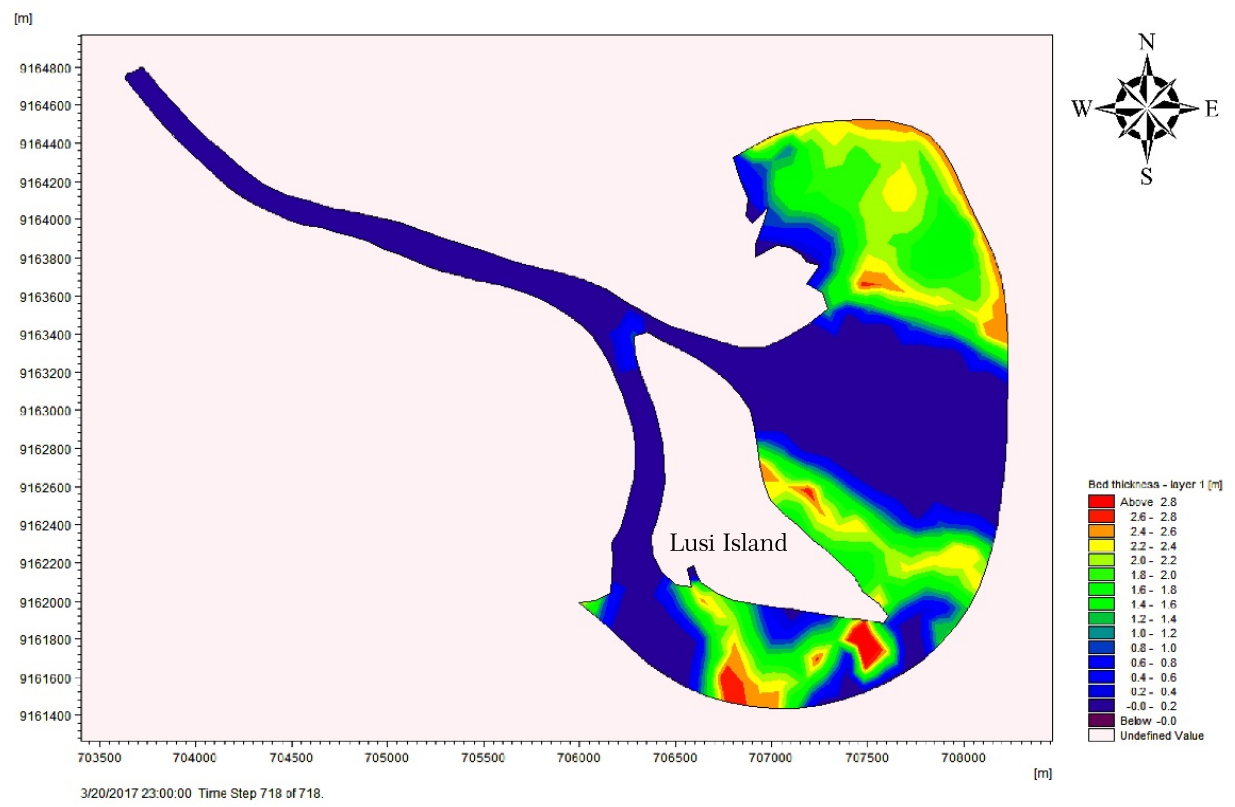

Fig. 7. Sediment suspended in Estuary of Porong River for 15 days.

\subsection{Sedimentation}

Sediment samples were taken at 3 stations. The result of laboratory analysis about sediment samples showed that at station 1, sand content was more dominant with percentage of $51.14 \%$, followed by fine grain (silt + clay) $48.68 \%$ and gravel $0.19 \%$. The sediment composition at stations 2 and 3 differs from station 1 . Station 2 and 3 is more dominated by fine grains (silt + clay) with composition of $81.30 \%$ and $67.41 \%$. The next composition is the sand of $18.56 \%$ and $32.46 \%$, while the gravel at stations 2 and 3 is only $0.14 \%$.

The sedimentation process with a 15-day simulation takes place on the north-east of Lusi Island with a thick sediment ranging from 1.6 to $2.6 \mathrm{~m}$ with gradations of green to light orange (Figure 8). In addition to the Northeast Lusi Island, sedimentation also occurs on the lower side or Southeast and South Lusi Island shown by green to red. The southern side has a larger sediment thickness than the Southeast side, it can be seen that the red color is more on the South side which shows the figure of $2.8 \mathrm{~m}$. Sediments on the Southeast side average around 2-2.4 $\mathrm{m}$.

Sedimentation occuring on the Northeast and Southeast side can be caused by the flow of currents from the river through the eastern branches. The current from that direction 
turns northeast to north and southeast and southward. At the moment the current flows towards the southern sediment hampered by the shape of Lusi Island. In addition, the accumulation of sediments is also due to tides, when the tide then sediment will be transported towards the estuary. This may affect althouh the tidal effect on this location is not very dominant.

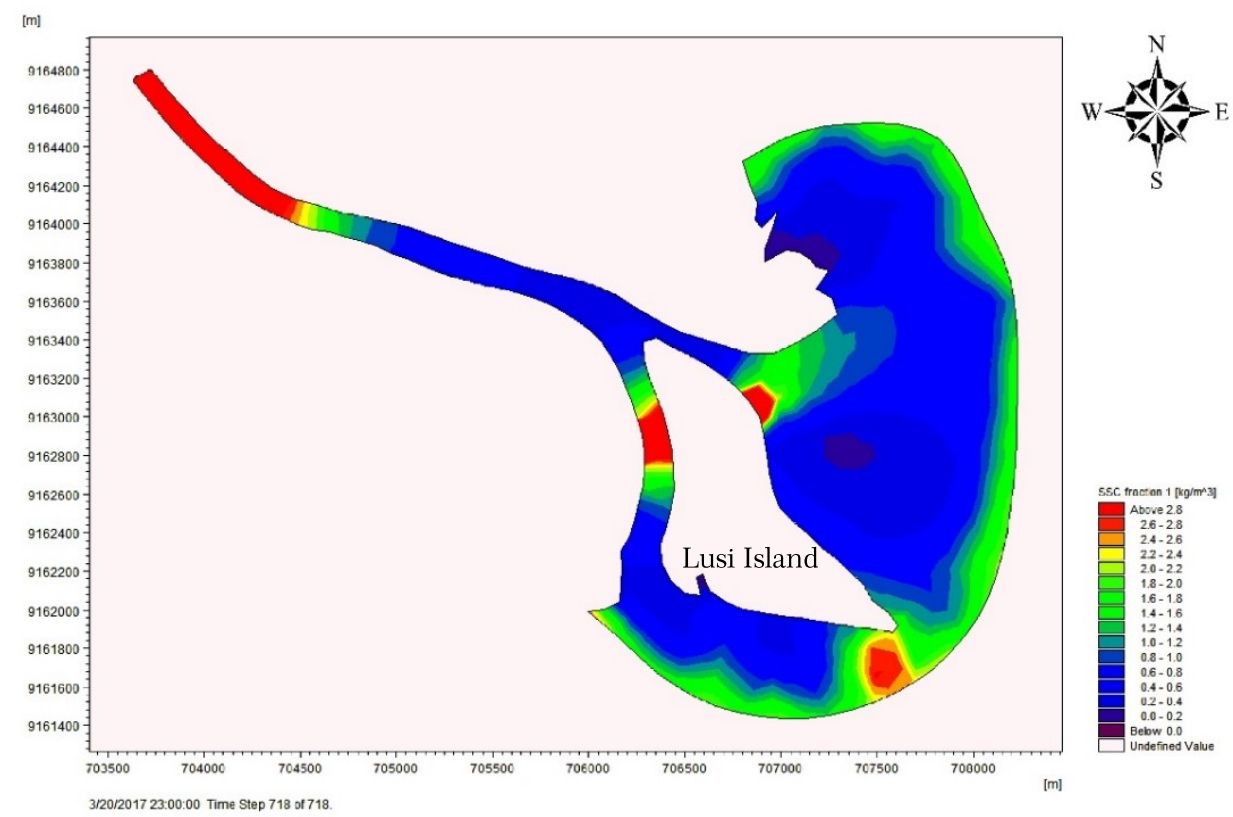

Fig. 8. Simulation of basic sediment in Estuary of Porong River for 15 days.

\section{Discussion}

The morphological changes of estuary of Porong river are strongly influenced by Oceanographic factors, such as currents and waves. From the results of data processing for the oceanographic parameters, it can be concluded that the influence of the change of estuary Porong most dominant in the wet season is caused by non tidal currents. Non-tidal currents are residual currents with varying effects. To find out the dominant cause of non tidal currents is done the data processing of river flow and wind data as input from wave. From the river flow data processing known the flow velocity of river discharge with average flow velocity of $578,9 \mathrm{~m}^{3} / \mathrm{s}$. Pahlevi et al. [14] also atated that the source of sediment material in the coastal area area is caused by Sidoarjo Coastal. There are many river estuaries that have relatively high river flow $\left(500 \mathrm{~m}^{3} / \mathrm{s}\right)$ plus since 2006 the abundance of sediment comes from Lapindo mudflow ehich is flowed into the Strait of Madura through Porong river. Wind data with a significant 10-year wind speed of $2.22 \mathrm{~m} / \mathrm{s}$ and an average speed of $1.41 \mathrm{~m} / \mathrm{s}$ is very weak to generate wave energy. From the analysis of river flow rate velocity and wave forecasting, river flow has the greatest influence on the change of the Porong River Estuary as evidenced by the current separation that is dominated by non tidal currents rather than tidal currents. River estuaries dominated by river discharges with relatively small waves will carry large amounts of upstream sediment transport.

Hydrodynamic model simulation shows that sediment suspension progresses toward the estuary until the estuary is not roo big, otherwise the sediment suspension that goes to the 
sea increases. This can happen because of the confluence of river and sea water so that the turbulence is greater and causes the sediment to rise.

Sedimentation occuring on the notheast and souteast side can be caused by the flow of currents from the river through the eastern branches. The current from that direction turns northeast to north and southeast and southward. At the moment the current flows towards the southern sedimen hamoered by the shape of Lusi Island. In addition, the accumulation of sediments is also due to tides, when the tide then sediment will be transported towards the estuary. This may affect although the tidal effect on this location is not very dominant

\section{Summary}

From this research, it can be concluded that (1) wind velocity is very weak to generate wave energy in the research location so that less give maximum contribution in change of Porong river estuary; (2) the dominant current at the Porong River Estuary is a nontidal flow; (3) estuary of Porong River can be classified as estuary type which is dominated by river discharge; (4) sedimentation process with a simulation of 15 days in the West Season occurred in the Northeast of Lusi Island with a thick sediment ranged from 1.6 to $2.6 \mathrm{~m}$; (5) the current results are very precise and the estuary of Porong river during the West Season is more dominated by the very high river flow.

We thank the Indonesian institutions that have contributed significant support and valuable information to the research: Ministry of Research, Technology and Higher Education, Republic of Indonesia and Hang Tuah University, Surabaya, Indonesia.

\section{References}

1. A. Harnanto. Peranan Kali Porong dalam mengalirkan lumpur Sidoarjo ke laut, Badan Pelaksana Badan Penanggulangan Lumpur Sidoarjo (BAPEL-BPLS) (2011).

2. T. C. Jennerjahn, I. Jänen, C. Propp, S. Adi, S. P. Mugroho. Environmental impact of mud volcano inputs on the anthropogenically altered Porong River and Madura Strait coastal waters, Java, Indonesia. Estuarine, Coastal and Shelf Science 130, 152-160 (2013)

3. N. Maryantika, C. Lin. Exploring changes of land use and mangrove distribution in the economic area of Sidoarjo District, East Java using multi-temporal Landsat images. Information Processing in Agriculture 4, 321-332 (2017)

4. A. S. Riyadi, B. Sarwono, Sudiwaluyo. Permodelan aliran sediment di Muara Kali Porong, Seminar Nasional Aplikasi Teknologi Prasarana Wilayah. ISBN 978-97918342-1-6 (2009).

5. H. Bachtiar, N. Fronto, R Fitri. Simple model of two dimensional sediment movement in Porong River. Journal of Marine Geological Institute 9 (3). ISSN 1693-4415 (2011).

6. W. Atmojo. Studi penyebaran sedimen tersuspensi di Muara Sungai Porong Kabupaten Pasuruan, Buletin Oseanografi Marina Oktober 1, ISSN 2089-3507, 60-81 (2011).

7. U. Hernawan, K. Budiono. Karakteristik dan distribusi lumpur Sidoarjo sepanjang Sungai, Estuari dan Perairan Porong. Jurnal Geologi Kelautan. 11(2), 91-99 (2013)

8. E. A. Kisnarti, V. D. Prasita, Perubahan morfologi di Muara Sungai Porong, Sidoarjo. Pertemuan Ilmiah Nasional Tahunan X ISOI. ISBN. 978-602-18153-2-8, 381-387 (2014).

9. E. A. Kisnarti, Pasang surut dan arus pasang surut di sekitar Muara Sungai Porong Sidoarjo. Jurnal Akuatika Indonesia. 1 (2). ISSN. 2528-052X, 101-108 (2016). 
10. A. D. Saputra, H. Setiyono, A. Anugroho, Pemetaan batimetri dan sedimen dasar di Perairan Karangsong, Kabupaten Indramayu, Jawa Barat. Buletin Oseanografi Marina 5(1). 38 - 43 (2016).

11. C. M. Simatupang, H. Surbakti, A. Agussalim, Analisis data arus di Perairan Muara Sungai Banyuasin Provinsi Sumatera Selatan. Maspari Journal, 8 (1), 15-24 (2016).

12. B. Triatmodjo, Teknik Pantai. Beta Ofset. Yogyakarta (1999).

13. Coastal Engineering Research Center. 1984. Shore Protection Manual. Departemen of the Army. Washington DC.

14. A.M. Pahlevi, Wiweka, Analisa sedimentasi di Muara Kali Porong akibat pembuangan lumpur Lapindo menggunakan data citra satelit Aster. Jurnal Ilmiah Geomatika, 16(2), 15-24 (2010). 